\title{
Demographic and Socio-economic Change in Ireland: A Spatial Perspective
}

Article · August 2008

DOI: $10.3366 /$ scot.2008.0035

\section{CITATIONS}

4

2 authors, including:

Cormac Walsh

University of Hamburg

43 PUBLICATIONS 213 CITATIONS

SEE PROFILE
READS

70

Some of the authors of this publication are also working on these related projects:

Project Soft Spaces in Europe View project

Nachhaltiges Landmanagement: Planungswissenschaftliche Expertise (Sustainable Land Management: Planning Expert Study) View project 


\section{DEMOGRAPHIC AND SOCIO-ECONOMIC Change in IRELAND: A SPATIAL Perspective}

\section{Cormac Walsh and Jim Walsh}

\section{INTRODUCTION}

It is widely accepted that Ireland has undergone a very significant transformation since the early 1990s. Since 1991 the population of the Republic of Ireland has expanded by over $20 \%$. Unprecedented and sustained levels of economic growth have served to reverse previous trends of emigration and unemployment, creating a new prosperity but also new challenges including increasing social polarisation and environmental responsibility. Not unlike the Scottish experience, the recent demographic turnaround in Ireland has to a significant extent been driven by net inmigration, including return migrants and economic migrants from the new accession states of central and eastern Europe. In direct contrast to the Scottish experience, however, natural increase has continued to represent a key component of demographic expansion in Ireland, leading to a significantly lower level of age dependency.

The changes that commenced around 1987 have been influenced by many factors including new forms of governance, national policies for economic and social development, a favourable international economic context, high levels of international investment in manufacturing and internationally traded

Cormac Walsh MSc is a doctoral student at the School of Geography, Planning and Environmental Policy, University College Dublin. Professor Jim Walsh is VicePresident of National University of Ireland, Maynooth, where he was Head of the Department of Geography 1995 - 2005. 
services, and also significant financial support from the European Union which was accompanied by easier access to enlarged EU markets. In addition there was a strong demographic dividend from the high birth rates of earlier decades which was also accompanied by a major transition in education levels (see Bartley and Kitchin 2007). The transformation has been multi-faceted and has resulted in a new geography of economic and social development with significant changes in relations between, and within, rural and urban areas, and in the roles of different places and spaces throughout Ireland. The very pace of economic growth and demographic expansion since the early 1990s has posed significant challenges as well as creating manifold opportunities. The experience of change and transformation, however, cannot be analysed in terms of quantitative indicators of growth and expansion alone. A qualitative shift has occurred in the geography of urbanisation with new emerging and evolving patterns of settlement structure and relations between urban and rural areas. Analysing and mapping (see Walsh 2007a) key demographic and socioeconomic indicators provides a unique opportunity to identify and explore emerging spatial patterns and trends associated with the changes since the late 1980 s, and, in particular, the spatial constructs that helped to define the human geography of Ireland at the start of the twenty first century. This article focuses on the spatial outcomes and policy implications of emerging patterns and trends of recent demographic and socio-economic change across the Republic of Ireland. Analysis is based primarily on spatially disaggregated data from the national Censuses of Population for the period 1991-2006.

\section{DEMOGRAPHIC CHANGE}

The demographic profile reflected in the 2002 Census of Population differs significantly from the profiles represented by previous censuses. In particular, in the period between 1996 and 2002 high levels of net in-migration exceeded annual levels of natural increase for the first time, and most significantly there was an expansion of population growth from the larger urban centres into the majority of the smaller towns, and indeed into the open countryside (see also Walsh et al. 2007a, b). The 2006 Census of Population recorded a usually resident population of 4,234,925 persons in the Republic of Ireland, the highest recorded population since 1861. Between 1851 and the first census of the new State taken in 1926 the total population declined by just over 2.1 million $(42 \%)$ to $2,972,000$. The subsequent expansion of over one million people between 1926 and 2006 occurred primarily in two phases; 1971 to $1981(+456,157$ or $15.6 \%)$ and 1991 to $2006(+709,206$ or $20.1 \%)$ coinciding 


\section{Demographic and Socio-economic Change in Ireland}

with periods of economic growth and net in-migration (see Figure 1 below). The geographical pattern of population change in the 1990s and current decade has been quite different from the patterns of earlier decades (Horner et al. 1987, Walsh 1991, Walsh 1996). Apart from the 1970s when there was a dispersed pattern of population growth, the dominant long-term trend was one of very severe decline in rural areas especially in the north midlands, northwest, west and southwest with population growth mainly confined to the larger urban centres and their hinterlands.

The net change in population over each inter-censal period is the outcome of changes in the vital birth and death rates on the one hand, and on the other hand, changes in net migration including inter-county movements and also movements into and out of the State. The total annual number of births peaked at over 74,000 in 1980 and thereafter went into a decline that lasted until 1994 when the total number was only 48,255 . Since then the number has risen steadily, reaching an annual average of 61,250 between 2002 and 2006, because of a number of factors including the 'echo' effects of the baby boom of the 1970s, together with deferred commencement of families. By contrast, the annual average death rate has declined slowly but continuously over the last thirty to forty years, to an annual average of 28,500 between 2002 and 2006.

The scale of net out-migration in the 1980s impacted severely on the pace of demographic change. In the late 1980s net out-migration from both urban and rural areas exceeded the overall level of natural increase and resulted in the first period of population decline since the 1950s. Following a gradual turn around in the pattern of migration, associated with improvements in the Irish economy and labour market, net immigration has become the norm since the mid-1990s, and since 2000 it has consistently exceeded the level of natural increase. By 2006 it is estimated that net in-migration was just over twice the level of natural increase.

Between 1996 and 2002, the proportion of immigrants in the total population increased significantly. Approximately 356,000 people, accounting for $9.2 \%$ of the usually resident population in 2002, were born outside the State in contrast with 210,000 or $5.8 \%$ in 1996 . In the twelve months prior to April 2006 the number of immigrants to Ireland is estimated to have been 86,000, the highest figure recorded since the commencement of the annual migration surveys in 1987 by the CSO. Net migration is estimated to account for twothirds of the population increase between 2005 and 2006. The most notable change since 2002 is the very large increase in migrants from the ten states 


\section{Scottish Affairs}

that joined the EU in May 2004, which accounted for $43 \%$ of the total immigrants over the 12 months prior to April 2006. Poland and Lithuania are by far the most important sources of recent immigrants. By contrast there has been a very substantial decline in the absolute and relative importance of immigrants who were born in Ireland. Whereas this group accounted for $44.6 \%$ of the total in 2001 , by 2006 the proportion was only $22.7 \%$.

\section{Figure 1}

\section{Components of Population Change 1911-2006}

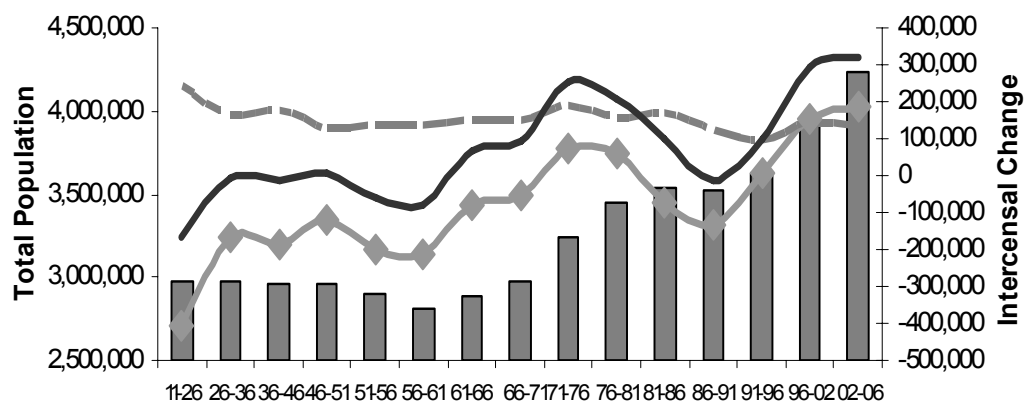

\begin{tabular}{|c|c|}
\hline Total Population & Estimated net migration \\
- - Natural increase & Change in population
\end{tabular}

At the sub-national level a very significant shift in the geography of population growth occurred over the 1991-2006 period (see Figure 2). Whereas the dominant historical trend has been one of increasing urbanisation and concentration of population within the larger urban centres, recent trends have been characterised by counterurbanisation and the dramatic expansion of the functional hinterlands of the larger urban centres. This pattern of periurban growth is particularly evident in the case of the Greater Dublin Area and the wider Leinster region, but is also found in the hinterlands of the smaller 


\section{Figure 2}

\section{Percentage Population Change 1991 - 2006}

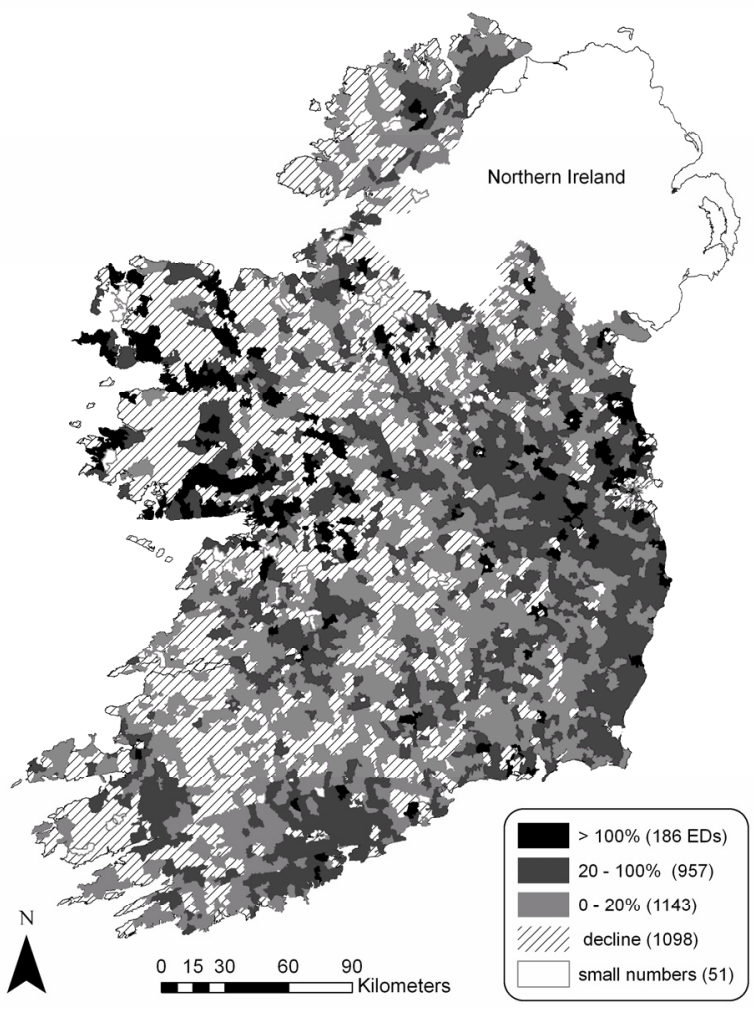

Mapping Sources: Central Statistics Office 1991 2006, Ordnance Survey Ireland Permit No. MP 009006 (C) Ordnance Survey Ireland, Government of Ireland. Map prepared by C. Walsh 2008. The mapping unit employed is the Electoral Division (ED), the smallest spatial unit for which Census of Population is available. The population of EDs vary significantly around an average of approximately 1200 persons. 


\section{Scottish Affairs}

cities of Cork, Galway and Limerick. Outside of the city hinterland areas, extensive areas of population decline are evident, particularly in more remote parts of the west and northwest. At the county level (NUTS IV), however, population increase has occurred in all 26 counties over the period since 1996, indicating the selective nature of migration to rural as well as urban areas.

Migration, which in the past led to pronounced differences in age profiles between urban and rural areas, became the main influence on changes in the size and structure of the population over the 1996-2006 period, particularly in some rural areas and in smaller urban centres, where net in-migration counterbalanced trends of natural decrease. A variety of processes are at work here including migration linked to purchasing a home at affordable prices, and immigration of workers from outside Ireland to small towns and rural areas to work in sectors such as tourism, personal services, construction and some traditional manufacturing industries. The combined effects have been widespread population growth at locations that are frequently at very long distances from the main workplaces. These changes in settlement have at times put high pressure on existing services and infrastructure and impacted negatively on the host communities, and on their traditional settlement forms. More generally, the recent trends have become the subject of intense debate in relation to various aspects of sustainability including the social, economic and environmental dimensions. They point to the need for a planning system that is both robust and flexible, and especially a need for strategies informed by detailed demographic analysis that will counteract recent negative trends that could be exacerbated in the years ahead when high levels of population increase are projected.

Significant differences in age profiles are evident between rural and urban areas, which are especially pronounced for the 20-29 age cohorts. The outcome of long term population movements is that the potential for rapid growth in population is mostly concentrated in the hinterlands of the cities and larger towns. In contrast to most of Western Europe, where the implications of age dependency are of significant economic, social and political concern, Ireland does not yet have a serious ageing problem, though the situation will change over the coming decades, especially in rural areas. Strong regional and urban-rural contrasts in the demographic vitality ratio suggest that spatial divergence in the age structure of the population is likely to become accentuated in the future. 


\section{Demographic and Socio-economic Change in Ireland}

One of the most important social changes of recent times has been the decline in marriage rates especially among those aged under thirty. This trend is also accompanied by significant differentials in marriage rates between rural and urban areas. The composition of family units is also undergoing some fundamental changes that may be related to an increasing incidence of (nonmarital) cohabitation, and the deferral of the commencement of family formation that in some cases is linked to participation in the labour force. The number of childless families has increased significantly. Almost two-thirds of the increase since the mid 1990s in the number of pre-school families (where the eldest child is aged less than four years) was made up of either single parent families or cohabiting couples. An urban-rural differentiation is evident in this shift in social behaviour. Empty-nest families are very evident in some of the more marginal rural areas reflecting persistent patterns of rural-urban migration. These areas are also characterised by high levels of elderly persons living alone, many of whom have some disability condition. The patterns identified here highlight the need to take account of social trends that are significantly altering the traditional perspective on family units, and to tailor family supports to the demographic conditions that prevail in different parts of the country (Walsh et al. 2007b).

\section{EduCATIONAL ATtAinMENT AND LABOUR FORCE PARTICIPATION}

The labour force participation rate, defined as the percentage of the population aged 15 years and over who are in the labour force, has increased significantly over the last two decades from $53.0 \%$ in 1981 to $60.9 \%$ in 2006 . This overall trend, however, masks contrasting trends between males and females. Female participation rates have increased from $29.7 \%$ to $47.0 \%$ between 1981 and 2002 and to almost $50 \%$ in 2006 , whereas male participation rates have declined from $76.4 \%$ to $69.9 \%$ over the same period.

The rise in female participation is particularly remarkable given the virtual stagnation that occurred throughout the twentieth century until the early 1980s. It is clearly associated with broad structural changes in both the economy and society that impacted upon the status and role of women in society. This change also represents, in part, a sectoral shift in employment, as a large number of women working on family farms in the past would, under the Principal Economic Status classification, be counted as outside the labour force. The substantial decline in family farming in recent decades removes this 


\section{Scottish Affairs}

methodological issue of 'dual status'. Legislative changes to support gender equality in the workplace and in the social welfare system, rising educational attainment among females, and declining rates of fertility, have all contributed to increase the opportunities and rewards for participation in the labour force. The rising cost of living and housing in particular has also in recent years become a salient factor, accelerating the trend towards dual-income households.

The contrasting decline in male labour force participation over this period is largely attributable to increased numbers in full-time education and a trend towards earlier retirement. In particular, the numbers of males aged over 65 years in employment has declined considerably, as many of those involved were engaged in farming and have increasingly availed themselves of the State old age pension

Education constitutes a key measure of accumulated human capital. Spatial variations in levels of educational attainment reflect a number of inter-related yet distinct factors, including the geography of employment in knowledge and skill-intensive industries, the spatial distribution of institutes of education, and third level education in particular and, to a significant degree, underlying differentials in demographic structure and population distribution. In turn, levels of educational attainment are a significant influencing factor in relation to employment diversification and local economic sustainability, more generally. From the national level to the local scale, high levels of educational attainment correlate strongly with proportionately high representation in the higher socio-economic groups. It is clear that the unprecedented levels of economic growth of the 'Celtic Tiger' years are in part attributable to the capacity of a highly skilled workforce to engage with the demands of a new global knowledge economy.

Since the introduction of free second level education in 1967 and high levels of state investment in all levels of education in subsequent decades, levels of education attainment have risen dramatically. Rising levels of education and high levels of computer literacy have been crucial factors in the maintenance and up-grading of employment, generating multi-national corporate investment in many parts of the State, despite increased competition from other semi-peripheral regions such as parts of Eastern and Southern Europe and other parts of the world. Increased skills and competence in information and communication technologies, in particular, have compensated for rising labour costs, enabling the fuller participation of enterprises based in Ireland in a global informational economy. 


\section{Demographic and Socio-economic Change in Ireland}

One of the most important social trends over recent decades has been the increase in the age at which full-time education ceases. In 1971 over threefifths $(62.4 \%)$ of the population aged 15 years and over whose full-time education had ceased left the educational system before reaching the age of 16 . By 1981 the proportion had dropped to $50 \%$ and it declined further to $40 \%$ by 1991. In 2002 the proportion was just under one-quarter at $24.4 \%$. Despite the general decline in the number of persons completing their formal education by the age of sixteen there were still almost 30,000 aged 15-19 in 2002 who had completed their education at either the primary or lower secondary levels. This subset amounting to $8.8 \%$ of the $15-19$ age cohort are generally very poorly prepared for participation in the labour force and are at risk of experiencing unemployment and related social challenges throughout their lives.

Levels of educational attainment vary considerably across the State, primarily due to uneven demand for skilled and unskilled labour and the differential distribution of persons in each age group. Additionally, regional variation in the provision of third level education significantly influences the spatial distribution of people with higher levels of education. In recent years, the spatial variation in educational attainment has been accentuated, with increasing regional disparities in terms of labour force skills.

\section{Travel AND SETtLement PATTERnS}

Radical changes in travel patterns for education and work occurred in the 1990s. Previous sections have recorded the most salient aspects of the context for changes in travel patterns. These include the increase in population and especially the extent to which that increase was dispersed over many areas; the more dramatic increase in the workforce, especially of women, in a restructured economy; and, accompanying the rise in general affluence, a very large increase in car ownership levels. Taken together these, and other factors, have contributed to new lifestyles that are increasingly dependent on motor cars as the dominant mode of transport, and which have resulted in travel patterns that underpin new types of rural-urban relations. Almost four-fifths $(78.3 \%)$ of all private households owned at least one car in 2002 compared with $66 \%$ in 1991 . In absolute terms the number of households with at least two cars almost trebled from 165,026 to 478,660 over the same period. Private households in rural areas generally have higher levels of car availability or dependency. 


\section{Scottish Affairs}

Housing construction has experienced exceptional growth since the mid 1990s onwards. Perhaps most significantly, housing development has become increasingly dispersed throughout rural and peri-urban areas as the commuter catchment areas of most large urban centres have expanded dramatically. This trend is most evident in relation to the construction of new single rural dwellings or 'one-off rural housing' which has been the focus of much debate. While the overall density of single rural dwellings remains low and the rate of increase is also modest, there are grounds for concern in some areas where high levels of urban sprawl, or in others where the provision of holiday homes, have significantly changed the landscape. The environmental impacts relate to potential contamination of ground water from septic tank seepage, and also to visual impacts arising from the scale and design of some of the new single rural dwellings. Gkartzios and Scott (2005) have identified the growth of dispersed single rural dwellings in the hinterland of Dublin city as a distinctive feature of Irish settlement patterns. They contend that much recent development of this nature within Dublin's rural hinterland may be described as 'displaced urbanisation', a displacement of population from existent urban areas due to a shortage of supply of affordable housing, following Mitchell's (2004) typology of counterurbanisation migratory movements. They also note, however, the existence of a strong preference for rural living in Ireland, based on an Irish 'rural idyll'. See Stockdale et al. (2000) for a discussion of counterurbanisation movements and their impacts on existing rural communities and settlement structures in Scotland.

Patterns of travel for education and work have changed considerably over the period since 1991. The most notable trends have been the decline in the numbers of school goers who either walk or cycle to school, and the very substantial increases in the numbers being transported to school by car. At the third level end of the education sector there is also evidence of rapid growth in the numbers of students commuting by car, including some who travel long distances from rural areas. For persons at work the dominant trends over recent times have been the extraordinary increase in the numbers driving to work by car, and the extension of the average distance travelled, and for the first time there is evidence on the duration of journeys to work with substantial numbers involved in journeys that take more than an hour each way (Walsh et al. 2007c). 


\section{Demographic and Socio-economic Change in Ireland}

\section{CONCLUSIONS}

One of the most notable aspects of demographic change since the mid 1990s was the widespread experience of rural repopulation, a trend that distinguishes the rural experience in Ireland from many other countries of Europe as well as marking a reversal of the depopulation trend that had characterised every intercensal period from the mid 19th century through to 1996. In areas that were previously characterised by long-term population decline there was a welcome reversal that can probably be largely attributed to in-migration attracted by improved employment opportunities and accessibility to urban centres. There were also increases throughout the extended hinterlands of Dublin and the other cities associated largely with one-off housing in the countryside. The emergence of these trends is a cause for concern as it typifies a move towards a settlement pattern that is unlikely to be sustainable from a social, economic or environmental perspective (Williams et al. 2007). At the same time the major areas of population decline shifted to certain parts of the cities (some older central areas and also parts of the middle suburbs) which will present further challenges for social and community development as well as for spatial planning and urban design.

The combined effects of economic restructuring and high levels of population growth impacted significantly on local housing markets and on travel patterns. Employment opportunities became increasingly concentrated in or near urban areas as the economy became more reliant on high-end manufacturing and internationally traded services. These trends have led to a dramatic increase in the demand for housing in areas within commuting distances of key urban areas and Dublin in particular (Williams et al. 2007, Van Egaraat and Breathnach 2007). With owner occupancy continuing to be the goal of the majority of the population, escalating house prices in the cities have contributed to increasing numbers seeking housing in small towns, villages and also in the open countryside, frequently at very considerable distances from the cities and other large towns (see Norris and Redmond 2007).

There has been a very substantial increase in the numbers of single rural dwellings, though this has not been universal. The issue has been particularly acute in some coastal areas and in areas adjacent to inland lakes where there has been the added contribution of second homes for leisure purposes. These developments represent to a large extent a new form of rural-urban relationship, with at times adverse consequences for the local communities of such areas. The politics of urban and rural development has become 


\section{Scottish Affairs}

increasingly contested, characterised by competing discourses of 'the rural' (Scott 2006, Scott et al. 2007) The trend of 'one-off housing' has been highly controversial and has necessitated the preparation of Sustainable Rural Housing Guidelines (DOEHLG 2005) which take account of different types of rural areas. Linked to the dispersal of new housing is the increasing length of journeys to work for rural residents, increasing journey times due to congestion, and longer journeys associated with the increasing number of carbased trips to workplaces, schools, and colleges for both urban and rural residents.

The spatial transformations discussed in this article pose significant challenges for spatial planning policy (Walsh 2007b). It is increasingly recognised that comprehensive spatially aware policy making requires the coordination of rural and urban policies to plan strategically for post-productivist rural areas and increasingly dispersed urban settlement structures (cf. Keating and Stevenson 2006, Purves 2006). At the national scale it is evident that current patterns of housing development are at odds with the objectives of National Spatial Strategy (DOELG 2002) in relation to metropolitan consolidation (of the Greater Dublin Area primarily) and balanced regional development. At a local scale the rapid pace of residential development in peri-urban areas has posed significant challenges for the coordinated provision of transport, education, healthcare and community facilities. Furthermore, recent population projections suggest that the scale of population growth over the next 15 years could be well in excess of the amount recorded for the period 1991-2006 (DOEHLG 2007, Central Statistics Office 2005). The increased complexity and spatial diversity associated with recent transformations increases the challenges but also the need for more robust spatial and demographic analysis to underpin strategic spatial planning based on shared conceptualisations of space and place at a number of geographical scales across all sectors of the economy, society and polity (Walsh 2008).

\section{REFERENCES}

Bartley, B. and Kitchin, R. (eds.) (2007) Understanding Contemporary Ireland, Dublin, Pluto Press.

Central Statistics Office (2005) Regional Population Projections, available at www.cso.ie/ Accessed 14/11/07.

Department Of Environment And Local Government (2002) The National Spatial Strategy 2002-2020: People, Places, Potential, Dublin, Stationery Office. 


\section{Demographic and Socio-economic Change in Ireland}

Department Of Environment Heritage And Local Government (2005) Sustainable

Rural Housing: Guidelines For Planning Authorities, Dublin, Stationary Office.

Department Of The Environment Heritage And Local Government (2007) National Population Projections And Regional Population Targets 2006 - 2020,

Dublin, Government Publications.

Gkartzios, M. and Scott, M. (2005) Countryside Here I Come: Urban Rural

Migration in the Dublin City-Region. Planning And Environmental Policy

Research Series Working Paper 05/01,. School Of Geography, Planning And

Environmental Policy, University College Dublin.

Horner, A., Walsh, J. A. and Harrington, V. (1987) Population In Ireland: A Census

Atlas, Dublin, Department Of Geography, University College Dublin.

Keating, M. and Stevenson, L. (2006) Rural Policy in Scotland after Devolution.

Regional Studies, 40, 397-407.

Mitchell, C. J. A. (2004) Making Sense Of Counterurbanisation. Journal of Rural

Studies 20, 15-34.

Norris, M. and Redmond, D. (eds.) (2007) Housing Contemporary Ireland: Policy,

Society and Shelter, London, Springer Press.

Purves, N. (2006) Quality And Connectivity: The Continuing Tradition of Strategic

Spatial Planning in Scotland. In Adams, N., Alden, J. and Harris, N. (eds.)

Regional Development and Spatial Planning in an Enlarged European

Union. Aldershot, Ashgate, 107-128.

Scott, M. (2006) Strategic Spatial Planning And Contested Ruralities: Insights from the Republic of Ireland. European Planning Studies, 14, 811-829.

Scott, M., Russell, P. and Redmond, D. (2007) Active Citizenship, Civil Society and Managing Spatial Change in the Urban-Rural Fringe. Policy and Politics, 35, 163-190.

Stockdale, A., Findlay, A. and Short, D. (2000) The Repopulation of Rural Scotland: Opportunity and Threat. Journal of Rural Studies, 16, 243-257.

Van Egaraat, C. and Breathnach, P. (2007) The Manufacturing Sector. In Bartley, B. and Kitchin, R. (eds.) Understanding Contemporary Ireland. Dublin, Pluto Press, $128-145$.

Walsh, C., Walsh, J. A. and Kavanagh, A. (2007a) Population Distribution and Change. In Walsh, J. A. (ed.) People And Place: A Census Atlas Of The Republic Of Ireland. Maynooth, National Institute For Regional And Spatial Analysis, 14-48. 


\section{Scottish Affairs}

Walsh, C., Walsh, J. A. and Kavanagh, A. (2007b) Population Structure. In Walsh, J. A. (ed.) People And Place: A Census Atlas Of The Republic Of Ireland. Maynooth, National Institute For Regional And Spatial Analysis, 50-92.

Walsh, J. A. (1991) The Turn-Around of the Turn-Around in the Population of the Republic of Ireland. Irish Geography, 24, 116-124.

Walsh, J. A. (1996) Population Change in the 1990s: Preliminary Evidence from the 1996 Census of Population in the Republic Of Ireland. Geographical Viewpoint, 24, 3-12.

Walsh, J. A. (ed.) (2007a) People and Place: A Census Atlas of the Republic Of Ireland, Maynooth, National Institute For Regional And Spatial Analysis.

Walsh, J. A. (2007b) Regional Development: Trends, Policies, Strategies. In Bartley, B. and Kitchin, R. (eds.) Understanding Contemporary Ireland. Dublin, Pluto Press, 44-56.

Walsh, J. A. (2008, In Press) Space and Place in the National Spatial Strategy for the Republic of Ireland. In Davoudi, S., Strange, I. and Whitney, D. (eds.) Critical Thinking About Space And Place In Strategic Spatial Planning. London, Routledge,

Walsh, J. A., Keaveney, K. and Foley, R. (2007c) Housing and Travel. In Walsh, J. A. (Ed.) People and Place: A Census Atlas of the Republic of Ireland. Dublin, National Institute For Regional And Spatial Analysis, Nuim, 242-284.

Williams, B., Hughes, B. and Shiels, P. (2007) SCS Housing Study 2007: Urban Sprawl and Market Fragmentation Within the Greater Dublin Area. Society Of Chartered Surveyors.

April 2008 